\title{
Influence of chitosan coating and packaging materials on the quality characteristics of fresh-cut cucumber
}

\author{
Ibukunoluwa Fola Olawuyi, Wonyoung Lee* \\ School of Food Science and Biotechnology, Kyungpook National University, Daegu 41566, Korea
}

\begin{abstract}
In this study, the influence of chitosan coating and packaging materials on the quality characteristics of fresh-cut cucumber during storage was examined. Fresh cucumber was cut into $10 \mathrm{~mm}$ thick slices and then coated with chitosan through immersion in $1 \%$ and $2 \%$ chitosan solutions while control samples (uncoated) were immersed in distilled water. Coated and uncoated fresh-cut samples were packaged in three different materials: $60 \mu \mathrm{m}$ low-density polyethylene (LDPE) film, polypropylene tray with $65 \mu \mathrm{m}$ casted polypropylene (CPP) film and $110 \mu \mathrm{m}$ composite polyamide-polyethylene (PAPE) film, and then sealed and stored at $5^{\circ} \mathrm{C}$ for 12 days. During this storage period, the gas composition, visual quality, weight loss, firmness, total soluble solids, $\mathrm{pH}$, color, and microbial quality of the samples were evaluated periodically. The fresh-cut samples coated with chitosan recorded better quality characteristics compared to those of uncoated samples. This result confirmed the significance of chitosan coating for preserving the quality of fresh-cut fruits. The samples stored in LDPE and CPP packaging materials without chitosan coating showed a decline in quality, while PAPE enhanced the barrier properties of chitosan coating and consequently improved the quality of fresh-cut cucumber during its storage. At the end of the storage period, $2 \%$ chitosan-coated and PAPE-packaged fresh-cut cucumber samples showed the best quality characteristics. Hence, we recommend the combined application of chitosan coating with PAPE package for better preserving the quality of fresh-cut cucumber.
\end{abstract}

Key words : fresh-cut cucumber, chitosan, packaging material, quality, storage

\section{Introduction}

Cucumber (Cucumis sativus L.) is an important fruit that is consumed globally for its fresh crispy taste, high nutritional value and great health benefits. However, it is perishable owing to its high moisture content and is not amenable for long-term storage even at low temperatures. The peculiar deteriorative changes in cucumbers during their storage and distribution are mostly due to their high respiration, yellowing, and loss of moisture leading to shriveling and consequently microbial decay (1). Processing of fruits into more convenient product is considered to be an appropriate strategy to reduce their postharvest losses.

*Corresponding author. E-mail : wonyoung@knu.ac.kr Phone : 82-53-950-7763, Fax : 82-53-950-7762

Received 17 July 2018; Revised 7 September 2018; Accepted 12 November 2018.

Copyright (c) The Korean Society of Food Preservation. All rights reserved.
Minimal processing of fruits into ready-to-eat products is a recent trend which has attracted the attention of consumers $(2,3)$. Currently, fresh-cut fruits are either packaged individually or as mixed fruits with others. Various fruits such as pineapple, watermelon, and apple are commonly sold in the market, but fresh-cut cucumber is yet to gain popularity globally. As the demand for fresh-cut fruits and vegetables is increasing, the shelf life of fresh-cut products is of concern, because their quality deteriorates during their storage. There have been various studies on extending the shelf life of certain fresh-cut fruits $(4,5)$, but very few on preserving fresh-cut cucumber. Techniques such as mild heat treatment, and cold temperature storage are used to preserve fresh-cut produces for long durations $(6,7)$. However, these treatments inevitably lead to the deterioration of some physiological and sensory characteristics of fresh-cut produces (8-10).

Recently, in order to maintain the quality and extend the shelf-life of fresh-cut products, edible coatings are applied 
or the produces are stored in modified atmospheric conditions (11-16). The applied coating essentially modifies the atmosphere surrounding the fruit/vegetable and ac as a semipermeable barrier that controls the gas exchange and water loss, and maintains the firmness of tissues, in addition to inhibiting microbial degradation of the produce (17).

Chitosan, a natural polysaccharide-based coating, regulates the internal tissue atmosphere, acts as a barrier to the movement of moisture, oxygen, carbon dioxide, and volatiles, and thus reduces the metabolism and delays the fruit senescence (18). The effect of the chitosan coating on the quality and safety of fruits has been studied extensively (19-22). After the coating of fresh-cut fruits, a suitable package may be required to protect them from further contamination and also to serve as a carrier during storage and distribution.

Packaging has a critical role in food storage and distribution. Apart from serving its primary function as a container, a packaging material must also meet the fundamental requirements of maintaining the food quality and safety during their storage. Packaging in polymer bags (such as polyethylene) is a commonly employed postharvest technique for maintaining the quality of fruits and vegetables during their storage and distribution (23). The field of food packaging has evolved over the years, as seen in the development of various beneficial polymer-based packaging materials with unique barrier properties against oxygen, moisture, light, volatiles, and both chemical and microbiological contamination $(24,25)$. For low-temperature storage, a polymer film is suitable for a modified atmosphere packaging (MAP) and has the advantage of low cost and easy implementation at the commercial level (26-28). The successful use of polymer films for MAP is based on their specific permeation to oxygen and carbon dioxide to generate an atmosphere that is suitable for the retention of the food quality during storage (26-28). The choice of the packaging material for a fresh-cut product is important for its effective storage and distribution. Hence, many studies have investigated the effects of packaging materials on the quality and shelf-life of fruits (28-30). However, only few studies investigated the combined effects of coating and packaging material on the quality of fresh-cut cucumber. Therefore, the present study aims to evaluate the quality characteristics of fresh-cut cucumber samples coated with chitosan and packaged in various polymer films during its storage.

\section{Materials and Methods}

\section{Fruits and materials}

Freshly harvested cucumber fruits (Cucumis sativus) were purchased directly from a local farm (Gwangju, Korea) and stored in a refrigerator at $5^{\circ} \mathrm{C}$ for $24 \mathrm{~h}$ until use. The fruits were selected based on their freshness, size, and greenness. Low-molecular chitosan powder $\left(100 \% ; 10.5 \mathrm{cps} / 20^{\circ} \mathrm{C}\right.$; Symbiosal Biotech Ltd., Mokpo, Korea) was used in this study because of its ease of solubility in the solvent. Analytical grade acetic acid was used (Daejung Chemical Ltd., Siheung, Korea). The fresh-cut fruits were packaged in $60 \mu \mathrm{m}$ low-density polyethylene (LDPE) film $(20 \mathrm{~cm} \times 30 \mathrm{~cm}$; Thai griptech, Thailand), polypropylene tray (G-12157; GMPack tray, Paju, Korea) with $65 \mu \mathrm{m}$ casted polypropylene (CPP) film (GMP CO., Ltd, Paju, Korea) used for heat-sealing, and $110 \mu \mathrm{m}$ composite polyamide-polyethylene (PAPE) film (20 $\mathrm{cm} \times 30 \mathrm{~cm}$; Solis, Switzerland). An airzero nozzle-type vacuum and gas flushing machine (AZ-450E) was used for heat sealing LDPE and PAPE, while a film adhesion machine (G320-Q12; GMP CO., Ltd, Paju, Korea) was used for heat sealing the CPP film to the tray.

Preparation of the chitosan coating solutions and experimental design

Distilled water was used as control ( $0 \%$ chitosan), while chitosan solutions were prepared using the method described by Ali et al. (31). For preparing $1 \%$ and $2 \%$ solutions, 10 and $20 \mathrm{~g}$ of chitosan powder respectively were dissolved in $1 \mathrm{~L}$ of distilled water $\left(60^{\circ} \mathrm{C}\right)$ containing $10 \mathrm{~mL}$ of glacial acetic acid and stirred using a magnetic stirrer for $5 \mathrm{~h}$. The $\mathrm{pH}$ of the coating solution was adjusted to 5.6 using $1 \mathrm{~N}$ $\mathrm{NaOH}$. The cucumber was washed with tap water and sliced uniformly into $-10 \mathrm{~mm}$ thick pieces. The slices were then divided into three portions for different treatments. A single-layer chitosan coating was achieved by completely submerging $500 \mathrm{~g}$ of the fresh-cut cucumber in $1 \mathrm{~L}$ of the aqueous chitosan solution for $2 \mathrm{~min}$ and then the coated samples were allowed to dry at room temperature for $30 \mathrm{~min}$ inside a cabinet with laminar air flow. Fresh-cut cucumber of $100 \mathrm{~g}$ were packed into each packaging materials, heat-sealed and stored at $5{ }^{\circ} \mathrm{C}, 60 \% \mathrm{RH}$ in the refrigerator. The samples were prepared in triplicates for each treatment and their qualities were analyzed at 3 day intervals over 12 days. 


\section{Headspace $\mathrm{CO}_{2}$ concentration}

The headspace gas compositions of the packaged samples were analyzed with a digital gas analyzer (Quantek Gas Analyzer, Model 902D, Grafton, USA). Gas concentration was measured by penetrating the package film containing the sample with the needle probe of the device. Values of $\mathrm{CO}_{2}$ concentration was recorded from the display screen on the instrument.

\section{Visual quality}

Visual quality was assessed using photograph figure of fresh-cut cucumber surface using an industrial camera (DFK 31AF03; Theimagingsource, Bremen, Germany) and visual quality score was assigned as previously described (32). The vsual quality was scored on a 1 to 9 scale, where 9 represents an excellent and fresh appearance, 7 represents good, 5 represents fair (limit of marketability), 3 represents fair (useable but not saleable), and 1 indicates that the product is unusable. Intermediate numbers were assigned where appropriate.

\section{Weight loss and texture}

The samples were weighted using laboratory-scale digital balance. Weight losses were determined by comparing the weights of the sample (initial weight, $100 \pm 3 \mathrm{~g}$ ) before and after the storage period. The values are expressed as weight loss percentages with regard to the initial weight.

Weight loss $(\%)=\left(\mathrm{W}_{\text {in }}-\mathrm{W}_{\text {fin }}\right) / \mathrm{W}_{\text {in }} \times 100$

where, $\mathrm{W}_{\text {in }}$ is the weight of the produce on the first day and $\mathrm{W}_{\text {fin }}$ is its weight on the final day.

Firmness was measured as the maximum force $(\mathrm{g})$ required to puncture the surface of fresh-cut cucumber. A penetration test was conducted on the surface of fresh-cut cucumber using a texture analyzer (Compac-100, Scientific Co., Tokyo, Japan) with a $5 \mathrm{~mm}$ diameter cylindrical probe. Samples were penetrated to a depth of $12 \mathrm{~mm}$. The speed of the probe per penetration was $3 \mathrm{~mm} / \mathrm{s}$. Four measurements were carried out for each packaged sample.

\section{Total soluble solids (TSS) and $\mathrm{pH}$}

Fresh-cut cucumber was homogenized, squeezed with cheesecloth, and the TSS and $\mathrm{pH}$ of the juice was analyzed. TSS (brix) was determined at $25^{\circ} \mathrm{C}$ using a digital refractometer (PAL-1; Atago Co. Ltd., Tokyo, Japan) and $\mathrm{pH}$ was measured with a pH meter (Mettler-Toledo AG8603,
Schwerzenbach, Switzerland).

Color quality

The colors of the peel and fresh-cut surface of the cucumber samples were measured with a chroma meter (CR-300; Minolta Co., Osaka, Japan). L*, $a^{*}$ and $b^{*}$ represents the lightness, redness, and yellowness respectively. Here, $b^{*}$ and color change $(\Delta \mathrm{E})$ are used to express the color quality of the peel and fresh-cut surface of cucumber respectively. $\Delta \mathrm{E}$ was calculated as follows;

$$
\Delta \mathrm{E}=\left[\left(\mathrm{L}_{2}-\mathrm{L}_{1}\right)^{2}+\left(\mathrm{a}_{2}-\mathrm{a}_{1}\right)^{2}+\left(\mathrm{b}_{2}-\mathrm{b}_{1}\right)^{2}\right]^{1 / 2}
$$

\section{Microbiological analysis}

All fresh-cut samples were analyzed for total bacteria count (TBC). For this, $10 \mathrm{~g}$ of fresh-cut cucumber was aseptically packed in a sample bag $(190 \times 300 \mathrm{~mm}, 3 \mathrm{M}$ Co. Yeoju, Korea $)$ and diluted with $90 \mathrm{~mL}$ of $0.1 \%$ peptone water. The samples were homogenized using a stomacher (SH-001, Shimskyu, Tokyo, Japan) at a high speed for $3 \mathrm{~min}$. The bacterial count was determined on plate count agar (PCA; Becton Dickinson, NJ, USA) after the incubation of the sample at $37^{\circ} \mathrm{C}$ for 48 $\mathrm{h}$ and is represented as $\log \mathrm{CFU} / \mathrm{g}$ of the sample.

\section{Statistical analysis}

All experiments were carried out in triplicates and the data were analyzed using IBM SPSS (V.20). The results are expressed as the mean \pm standard deviation. Significant differences in means were calculated by analysis of variance (ANOVA) and Duncan multiple comparison test at $95 \%$ significance level.

\section{Results and discussion}

\section{$\mathrm{CO}_{2}$ concentration}

The headspace $\mathrm{CO}_{2}$ concentration for all the samples at $5^{\circ} \mathrm{C}$ is shown in Fig. 1. The $\mathrm{CO}_{2}$ concentration increased throughout the storage period. Fresh-cut products generally have a higher respiration rate than whole products, probably due to the increased surface area exposed to the atmosphere and the increased metabolic activity of injured tissues (33). Higher accumulation of $\mathrm{CO}_{2}$ was observed in PAPE-packaged samples than in CPP- and LDPE-packaged samples. However, no obvious physiological defects and no off-flavor were observed in samples packaged in PAPE. The gas permeability of packaging materials has been reported to affect the $\mathrm{O}_{2}$ 
concentration and consequent accumulation of $\mathrm{CO}_{2}$ in packaged fresh-cut papaya (34). Changes in the $\mathrm{CO}_{2}$ concentration in the packages were also affected by chitosan coating, as respiration was more pronounced in uncoated samples than in chitosan-coated samples. A significant difference $(\mathrm{p}<0.05)$ was observed between samples coated by different concentrations of chitosan solution (1 and 2\%) and uncoated $(0 \%)$ samples, with $2 \%$ chitosan-coated CPP-packaged and LDPE-packaged samples showing the lowest $\mathrm{CO}_{2}$ concentrations of 10.3 and $9 \%$, respectively. This result suggests that chitosan coating is useful for slowing

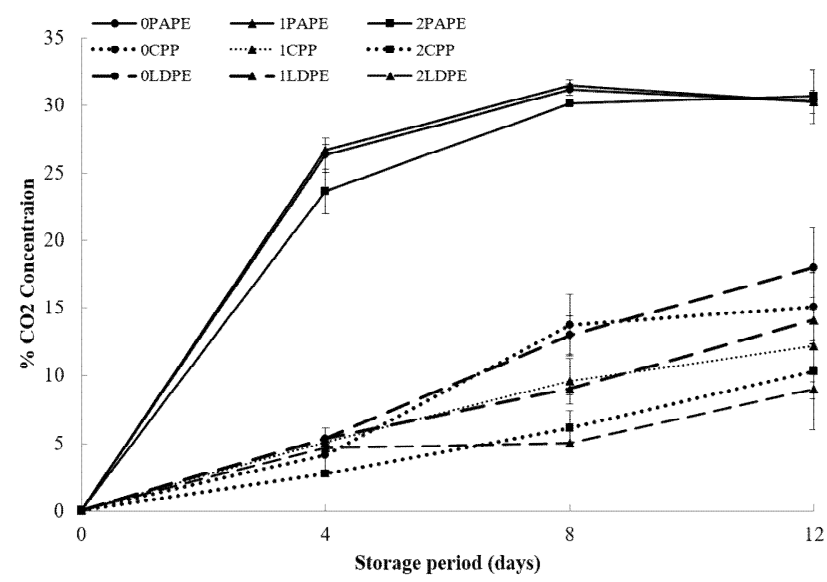

Fig. 1. Effect of chitosan coating and packaging material on $\mathrm{CO}_{2}$ concentration of fresh-cut cucumber during storage.

0,1 , and 2 represent \% chitosan concentration, PAPE (polyamide-polyethylene), CPP (casted propylene film+polypropylene tray), and LDPE (low-density polyethylene) packaging materials. down the respiration rate of fresh-cut cucumber. The tolerance of most fruits and vegetables to high $\mathrm{CO}_{2}$ concentrations has been established (35). Hence, it is important to identify safe concentrations that will result in maximum commodity storage life without injury $(35,36)$. In this study, a high $\mathrm{CO}_{2}$ concentration of $-30 \%$ was observed after 12 days, indicating that the storage life of fresh-cut cucumber was extended without a remarkable decline in the fruit quality. A similar result was also reported for chemically treated fresh-cut papaya, for which a high $\mathrm{CO}_{2}$ concentration (up to $41 \%$ ) was recorded. The papaya fruit was found to still maintain better quality parameters compared to those of untreated samples after storage (34).

\section{Visual quality}

The visual quality score revealed a gradual decrease in the perceived quality of fresh-cut cucumber during its storage. Both chitosan coating and packaging material significantly affected the visual quality of fresh-cut cucumber, as shown in Fig. 2. Uncoated samples packaged in CPP and LDPE had already decayed at the end of the 12-day storage, while the PAPE-packaged sample showed better properties owing to the prevention decay. The coated samples packaged with PAPE and CPP had better visual ratings than samples packaged in LDPE. Overall, 2\% chitosan-coated, PAPEpackaged fresh-cut samples had the best appearance after the 12 day storage period. Edible coating and packaging materials can slow down the deteriorative changes in products by
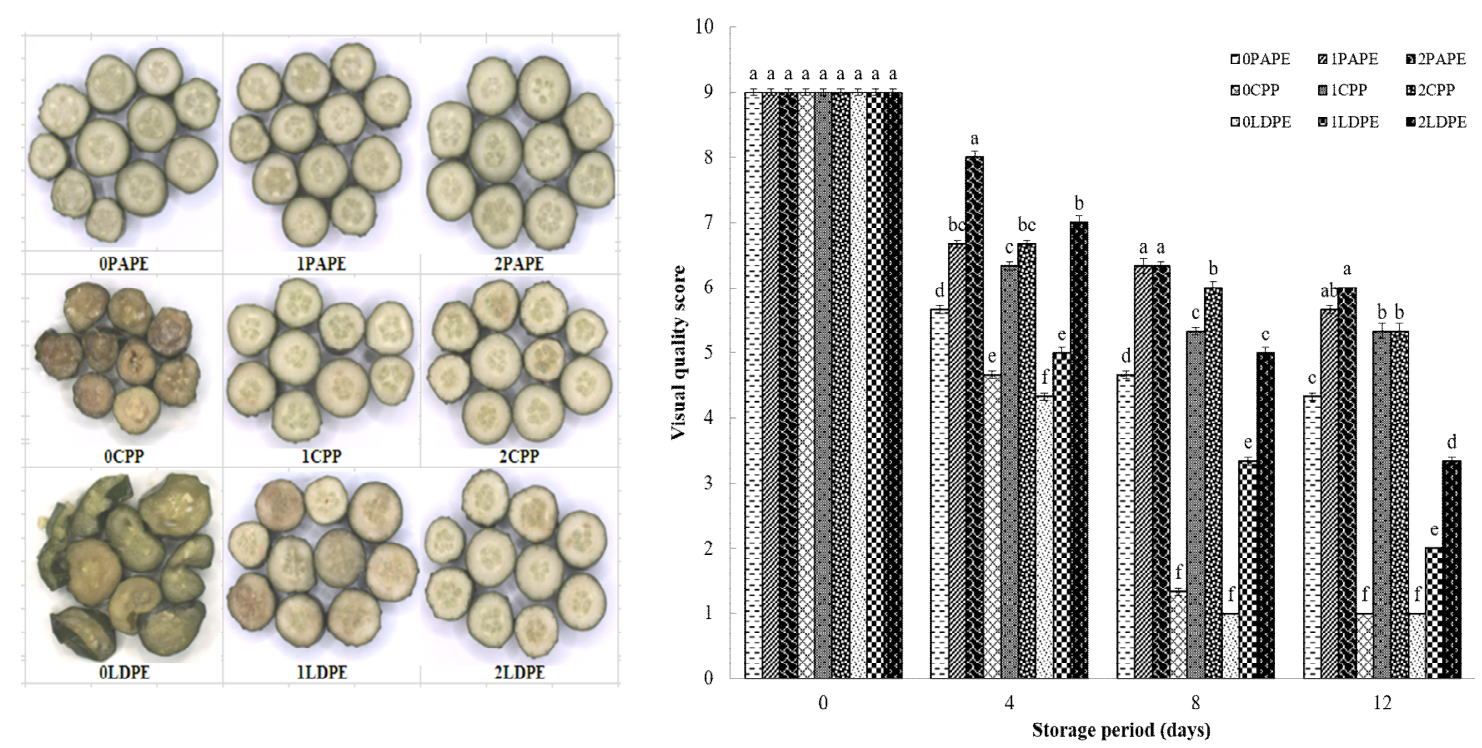

Fig. 2. Visual appearance of fresh-cut cucumber stored for 12 days.

0,1 and 2 represent \% chitosan concentration, PAPE (polyamide-polyethylene), CPP (casted propylene film + polypropylene tray), and LDPE (low-density polyethylene) packaging materials. 
reducing desiccation. According to a previous report, the visual quality of broccoli was also maintained using different packaging materials to create a modified atmosphere during its storage (32).

\section{Weight loss and texture}

Moisture content is an important quality parameter of fruits, which is assessed by the loss in their weight. Fresh-cut fruits are highly susceptible to weight loss (36). Therefore, it is important to evaluate the weight loss during their storage (37). As shown in Fig. 3, all samples lost weight during the storage period. By reducing the water transfer, chitosan coating combined with packaging materials minimized the weight loss during the storage period, leading to delayed dehydration (38). Tissue disintegration caused by microbial decay was observed in uncoated fresh-cut samples packaged in LDPE and CPP, which caused a surge in the weight difference, resulting in high calculated weight loss (over 2\%) after 4 days and 8 days of storage. These results indicate that the coating may be combined with LDPE and CPP packaging to improve their moisture barrier properties and reduce weight loss in fresh-cut fruits. Ali et al. (31) also reported the lowest weight loss in chitosan-coated bell pepper after storage for 20 days. Among the packaging materials, PAPE showed better moisture barrier properties for both chitosan-coated and uncoated samples. At the end of the storage period, $2 \%$ chitosan-coated fresh-cut cucumber packaged in PAPE showed the lowest percentage weight loss.

Firmness is also an important parameter that determines the quality and postharvest shelf-life of a fruit (39). Fresh-cut

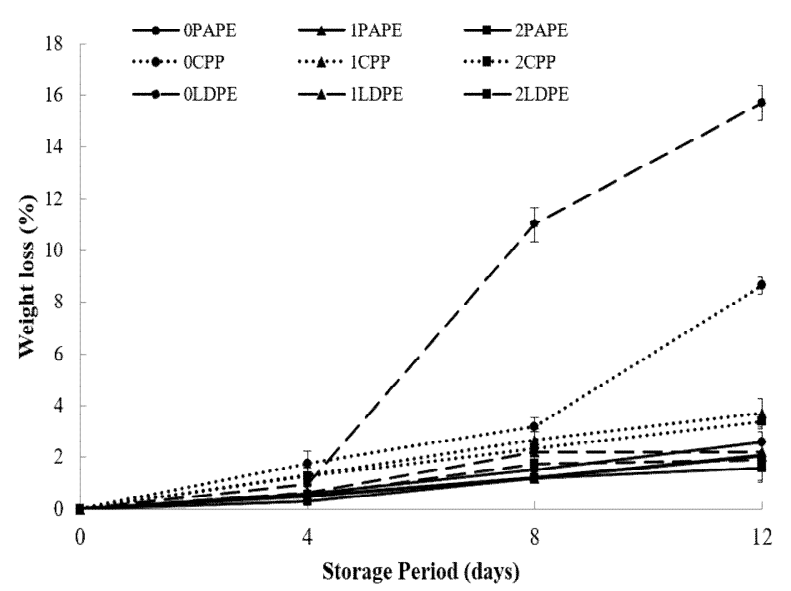

Fig. 3. Effect of chitosan coating and packaging material on weight loss of fresh-cut cucumber during storage.

0,1 , and 2 represent \% chitosan concentration, PAPE (polyamide-polyethylene), CPP (casted propylene film + polypropylene tray), and LDPE (low-density polyethylene) packaging materials. fruits and vegetables may lose their firmness owing to loss of moisture, microbial decay, ripening, tissue degradation, etc. As shown in Fig. 4, all samples suffered a loss in firmness (softened) during their storage. Fruit softening is caused by the action of tissue-degrading enzymes (40). Uncoated samples in LDPE and CPP suffered a drastic loss in firmness with $-95 \%$ loss in firmness after the storage period. Apart from the loss of moisture, microbial decay casued a huge loss in the firmness of these samples. This speculation can be confirmed by the result of microbial analysis (Fig. 7) and monitoring of the visual quality (Fig. 2). Further, reduction in crispiness and tensile strength were also observed by the firmness test, which may be attributed to the dry surface and easy breakage caused by the loss of moisture. Chitosan-coated samples ( 1 and $2 \%$ ) better retained their firmness than uncoated samples. This result is in agreement with those of other studies $(31,41,42)$, wherein chitosan coating was found to be effective for suppressing factors that induce fruit softening and thus thence improve the firmness of coated fruits.

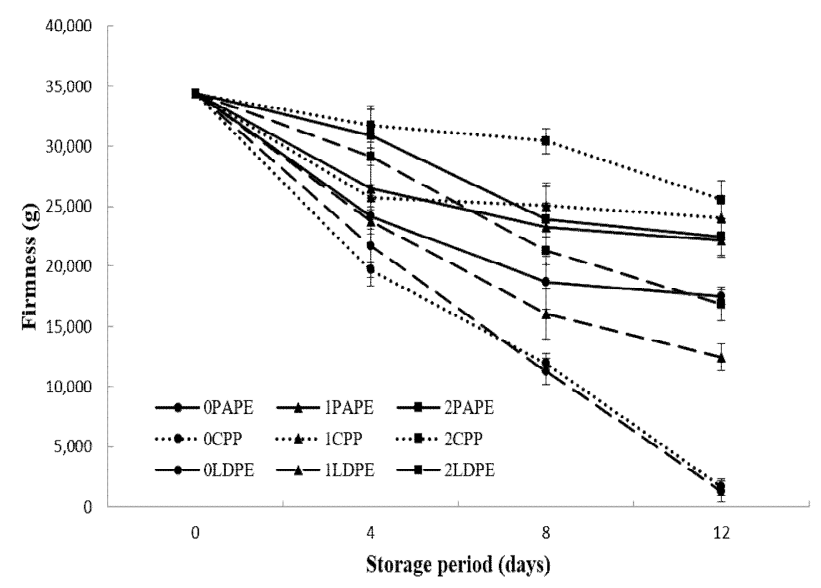

Fig. 4. Effect of chitosan coating and packaging material on texture of fresh-cut cucumber during storage.

0,1 , and 2 represent \% chitosan concentration, PAPE (polyamide-polyethylene), CPP (casted propylene film + polypropylene tray), and LDPE (low-density polyethylene) packaging materials.

\section{Total soluble solids (TSS) and $\mathrm{pH}$}

The TSS content determined as the brix value decreased in case of all treatments during the storage (Table 1). Chitosan coating and packaging materials had significant effects $(p<0.05)$ on the TSS content. Moreover, the concentration of chitosan solution was observed to significantly affect the conservation of sugar in coated fresh-cut samples. The TSS content is closely related to the ripening of fruits (43). Overall, $2 \%$ chitosan-coated, PAPE-packaged samples have the 
Table 1. Total soluble solids of fresh-cut cucumber stored for 12 days

\begin{tabular}{|c|c|c|c|c|}
\hline \multicolumn{2}{|r|}{ Tota } & \multicolumn{3}{|c|}{ soluble solids (TSS) } \\
\hline Storage (days) & 0 & 4 & 8 & 12 \\
\hline OPAPE & $3.63 \pm 0.04^{\mathrm{a}}$ & $3.30 \pm 0.00^{b}$ & $3.00 \pm 0.00^{\text {cd }}$ & $2.85 \pm 0.07^{\text {cd }}$ \\
\hline 1PAPE & $3.63 \pm 0.04^{\mathrm{a}}$ & $3.30 \pm 0.00^{b}$ & $3.05 \pm 0.07^{\mathrm{bc}}$ & $2.95 \pm 0.07^{\mathrm{bc}}$ \\
\hline 2PAPE & $3.63 \pm 0.04^{\mathrm{a}}$ & $3.45 \pm 0.07^{\mathrm{a}}$ & $3.30 \pm 0.08^{a}$ & $3.10 \pm 0.00^{\mathrm{a}}$ \\
\hline ОСРP & $3.63 \pm 0.04^{\mathrm{a}}$ & $3.05 \pm 0.07^{\mathrm{ef}}$ & $3.00 \pm 0.00^{\text {cd }}$ & $2.75 \pm 0.07^{\mathrm{d}}$ \\
\hline 1CPP & $3.63 \pm 0.04^{\mathrm{a}}$ & $3.15 \pm 0.07^{\mathrm{cd}}$ & $3.10 \pm 0.00^{b}$ & $3.00 \pm 0.08^{\mathrm{ab}}$ \\
\hline $2 \mathrm{CPP}$ & $3.63 \pm 0.04^{\mathrm{a}}$ & $3.20 \pm 0.00^{\mathrm{c}}$ & $3.15 \pm 0.00^{b}$ & $3.05 \pm 0.07^{\mathrm{ab}}$ \\
\hline OLDPE & $3.63 \pm 0.04^{\mathrm{a}}$ & $3.00 \pm 0.08^{\mathrm{f}}$ & $2.7 \pm 0.07^{\mathrm{e}}$ & $2.45 \pm 0.07^{\mathrm{e}}$ \\
\hline 1LDPE & $3.63 \pm 0.04^{\mathrm{a}}$ & $3.10 \pm 0.00^{\mathrm{de}}$ & $2.95 \pm 0.07^{\mathrm{d}}$ & $2.85 \pm 0.07^{\mathrm{cd}}$ \\
\hline 2LDPE & $3.63 \pm 0.04^{\mathrm{a}}$ & $3.40 \pm 0.00^{\mathrm{a}}$ & $3.10 \pm 0.00^{b}$ & $2.95 \pm 0.07^{b c}$ \\
\hline
\end{tabular}

Means within same column with different letters are significantly different $(\mathrm{p}<0.05)$. 0,1 , and 2 represent $\%$ chitosan concentration, PAPE (polyamide-polyethylene), CPP (casted propylene film + polypropylene tray), and LDPE (low-density polyethylene) packaging materials.

highest brix value. Jiang and Li (44) observed a higher TSS value for longan fruits treated with a higher concentration of chitosan and stated that increasing the concentration of chitosan coating led to markedly enhanced beneficial effects. The $\mathrm{pH}$ of fresh-cut cucumber samples continuously increased during the storage period (Table 2). This increase may be attributed to their aging/ripening during storage. Chitosan coating significantly $(\mathrm{p}<0.05)$ lowered the $\mathrm{pH}$ of coated samples compared to those of uncoated fresh-cut cucumber samples. A similar result was obtained by Shao et al, (45) who also reported a lower $\mathrm{pH}$ value in chitosan-coated apple.

Table 2. $\mathrm{pH}$ of fresh-cut cucumber stored for 12days

\begin{tabular}{ccccc}
\hline \multicolumn{5}{c}{$\mathrm{pH}$} \\
\hline Storage (days) & 0 & 4 & 8 & 12 \\
\hline OPAPE & $5.83 \pm 0.02^{\mathrm{a}}$ & $6.70 \pm 0.01^{\mathrm{a}}$ & $6.65 \pm 0.00^{\mathrm{b}}$ & $6.71 \pm 0.02^{\mathrm{d}}$ \\
1PAPE & $5.83 \pm 0.02^{\mathrm{a}}$ & $6.48 \pm 0.01^{\mathrm{e}}$ & $6.56 \pm 0.01^{\mathrm{c}}$ & $6.61 \pm 0.01^{\mathrm{e}}$ \\
2PAPE & $5.83 \pm 0.02^{\mathrm{a}}$ & $6.66 \pm 0.02^{\mathrm{b}}$ & $6.52 \pm 0.01^{\mathrm{d}}$ & $6.58 \pm 0.03^{\mathrm{f}}$ \\
0CPP & $5.83 \pm 0.02^{\mathrm{a}}$ & $6.55 \pm 0.01^{\mathrm{d}}$ & $6.64 \pm 0.01^{\mathrm{b}}$ & $6.94 \pm 0.02^{\mathrm{a}}$ \\
1CPP & $5.83 \pm 0.02^{\mathrm{a}}$ & $6.60 \pm 0.01^{\mathrm{c}}$ & $6.47 \pm 0.01^{\mathrm{f}}$ & $6.74 \pm 0.02^{\mathrm{c}}$ \\
2CPP & $5.83 \pm 0.02^{\mathrm{a}}$ & $6.45 \pm 0.00^{\mathrm{f}}$ & $6.47 \pm 0.02^{\mathrm{f}}$ & $6.70 \pm 0.01^{\mathrm{d}}$ \\
0LDPE & $5.83 \pm 0.02^{\mathrm{a}}$ & $6.53 \pm 0.01^{\mathrm{d}}$ & $6.49 \pm 0.01^{\mathrm{e}}$ & $6.96 \pm 0.01^{\mathrm{a}}$ \\
1LDPE & $5.83 \pm 0.02^{\mathrm{a}}$ & $6.49 \pm 0.02^{\mathrm{e}}$ & $6.58 \pm 0.01^{\mathrm{c}}$ & $6.82 \pm 0.02^{\mathrm{b}}$ \\
2LDPE & $5.83 \pm 0.02^{\mathrm{a}}$ & $6.55 \pm 0.02^{\mathrm{d}}$ & $6.53 \pm 0.01^{\mathrm{d}}$ & $6.75 \pm 0.03^{\mathrm{c}}$ \\
\hline
\end{tabular}

Means within same column with different letters are significantly different $(\mathrm{p}<0.05)$. 0,1 , and 2 represent $\%$ chitosan ccentration, PAPE (polyamide-polyethylene), CPP (casted propylene film + polypropylene tray), and LDPE (low-density polyethylene) packaging materials.

\section{Color quality}

Color is one of the most important indicator of the quality of cucumber during its storage (46). Color change $(\Delta \mathrm{E})$ and $b^{*}$ were used to evaluate the discoloration of fresh-cut surface and peel of cucumber samples respectively. Discoloration is a common quality defect observed in fresh-cut cucumber during storage (46). As shown in Fig. 5, discoloration of the fresh-cut surface (as indicated by an increase in $\Delta \mathrm{E}$ ) was observed in all samples but it was more severe in uncoated LDPE-packaged samples. A $\Delta \mathrm{E}$ value in the range of 0.5-1.5 indicates little color difference, that in the range of 1.5-3.0 represents a slight difference, whereas $\Delta \mathrm{E}$ values in the range of 3.0-6.0 and 6.0-12 indicate remarkable and extremely significant differences, respectively (47). After the storage period, 2\% chitosan-coated, PAPE-packaged samples had the lowest $\triangle \mathrm{E}$ value (less than 3 ), indicating a slight color difference, compared to those of the other samples. Chitosan coating and packaging materials have been used by several authors to delay color changes in fruits (48-50).

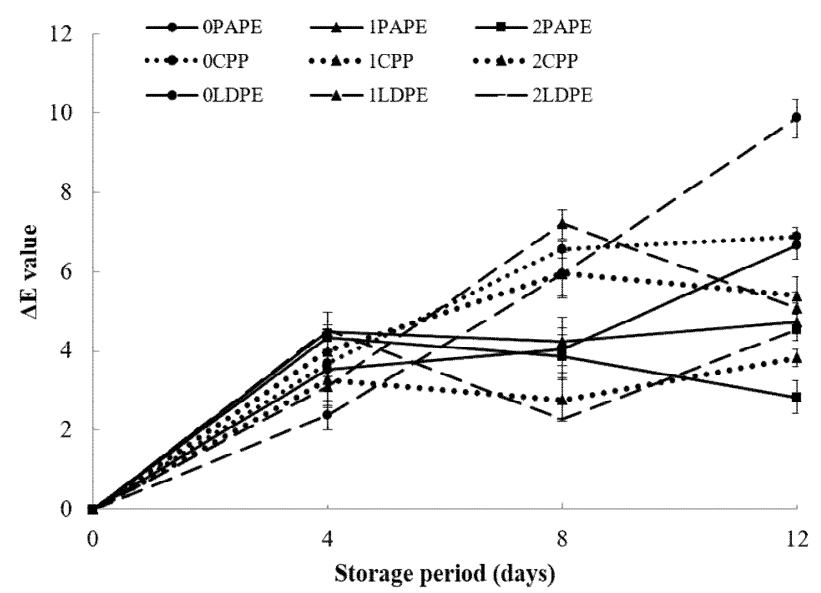

Fig. 5. Effect of chitosan coating and packaging material on color change of fresh-cut surface during storage.

0,1 , and 2 represent \% chitosan concentration, PAPE (polyamide-polyethylene), CPP (casted propylene film + polypropylene tray), and LDPE (low-density polyethylene) packaging materials.

As shown in Fig 6, all samples showed an increase in $b^{*}$ during the storage period. The discoloration (as indicated by an increase in $b^{\star}$ ) was found to be more severe in uncoated samples than in samples coated with chitosan. There were also no significant differences $(\mathrm{p}>0.05)$ in $\mathrm{b}^{*}$ values among the CPP- and LDPE-packaged samples until 8 days of storage. However, the difference in $b^{*}$ value of samples coated with different concentrations of chitosan (1 and 2\%) was significant $(\mathrm{p}<0.05)$ in case of all packaging materials, with $2 \%$ chitosan-coated, PAPE-packaged sample having the lowest value and the uncoated LDPE sample having the highest $b^{*}$ value after the 12-day storage period. Overall, coating with chitosan significantly reduced the color change in the peel 

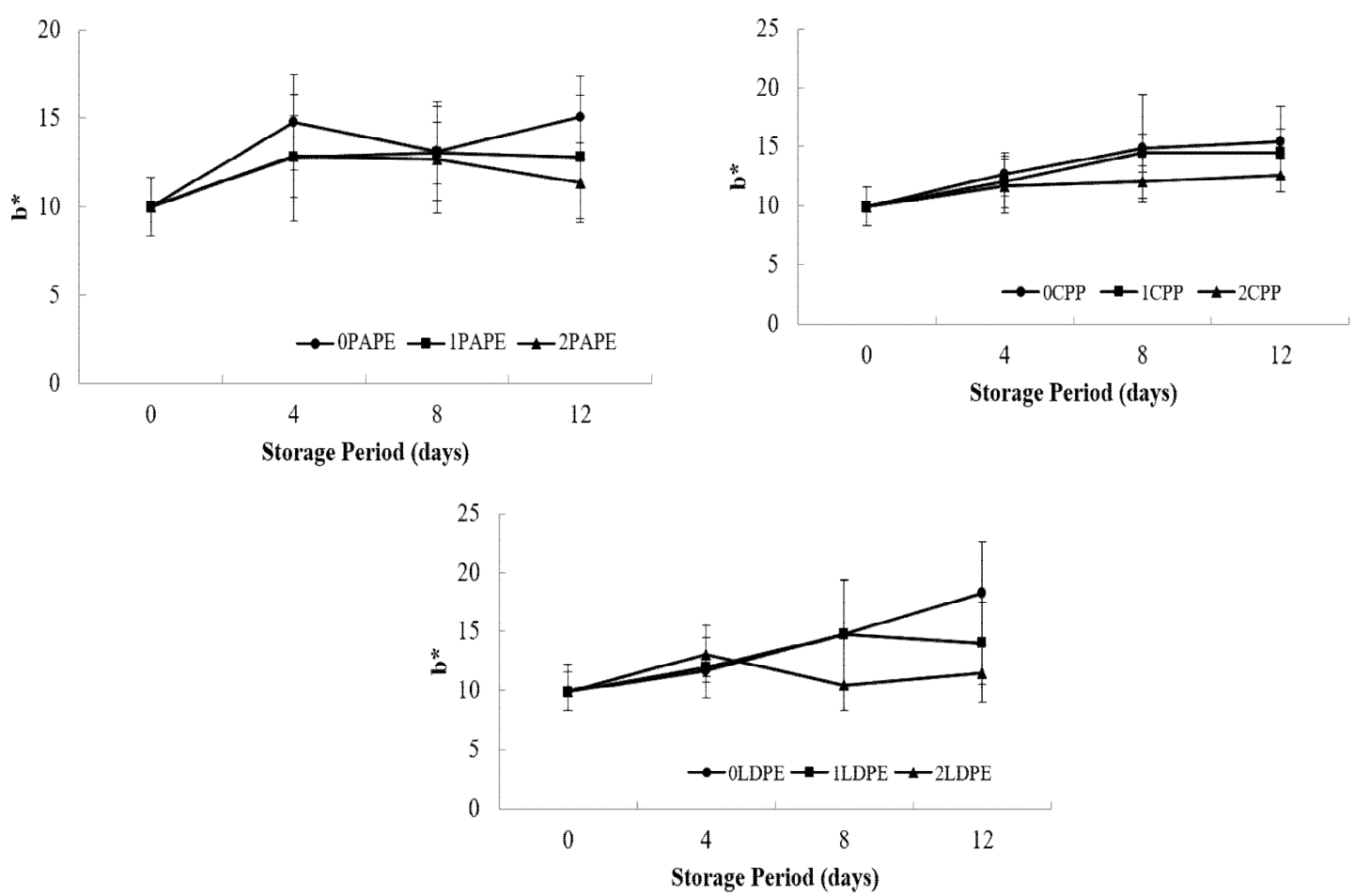

Fig. 6. Effect of chitosan coating and packaging material on peel $b^{*}$ of fresh-cut cucumber during storage.

0,1 , and 2 represent \% chitosan concentration, PAPE (polyamide-polyethylene), CPP (casted propylene film + polypropylene tray), and LDPE (low-density polyethylene) packaging materials.

of fresh-cut samples. This might be becaused chitosan coating is capable of retarding the degradation of chlorophyll in the cucumber peel (51). The preservative properties of the packaging material in maintaining the natural green color of the cucumber peel, as sobserved in this present study, is in the order of PAPE > CPP > LDPE. Jia et al. (32) reported that packagings material inhibit yellowing and deterioration of the color broccoli florets.

\section{Microbiological analysis}

Achieving microbial safety in fresh-cut fruits is of crucial concern because they have exposed tissues, which can be easily contaminated (52). The total bacterial count (TBC, Fig. 7) reveals the effectiveness of chitosan coating in reducing the bacterial load. After 4 days of Storage, all chitosan-coated (1 and 2\%) fresh-cut samples had a lower bacterial count. This result agrees with that reported by $\mathrm{Li}$ et al. (53) who also reported the effectiveness of chitosan coating as an antimicrobial agent. Park et al. (54) observed a reduction of 2.5 and $2 \log \mathrm{CFU} / \mathrm{g}$ in the counts of Cladosporium $s p$. and Rhizopus sp., respectively, in strawberries coated with a chitosan-based edible film, immediately after the application of the coating. In this study, an increase in the TBC was observed during the storage period. No substantial difference in microbial reduction was observed between the different packaging materials. $2 \%$ chitosan-coated, PAPE-packaged fresh-cut cucumber samples had the lowest (log CFU/g) bacterial count after 12 days of storage.

\section{Conclusion}

The importance of chitosan coating in the preservation of fresh-cut fruits is further corroborated in this study. This study revealed that fresh-cut cucumber samples coated with chitosan using a $2 \%$ solution performed better in improving and preventing the deterioration of the quality of the samples during their storage. However, the effectiveness of this treatment goes alongside a suitable choice of a packaging material for storage. The commonly used LDPE film showed poor ability in maintaining the fruit quality, and hence may not be suitable in the absence of a preventive coating. PAPE performed better among the packaging materials evaluated in this study. Further studies are required to evaluate the effects of these treatments on the nutritional and sensory properties of fresh-cut cucumber. In general, chitosan coating enhanced the ability of packaging materials in the preservation of the quality of fresh-cut cucumber. 


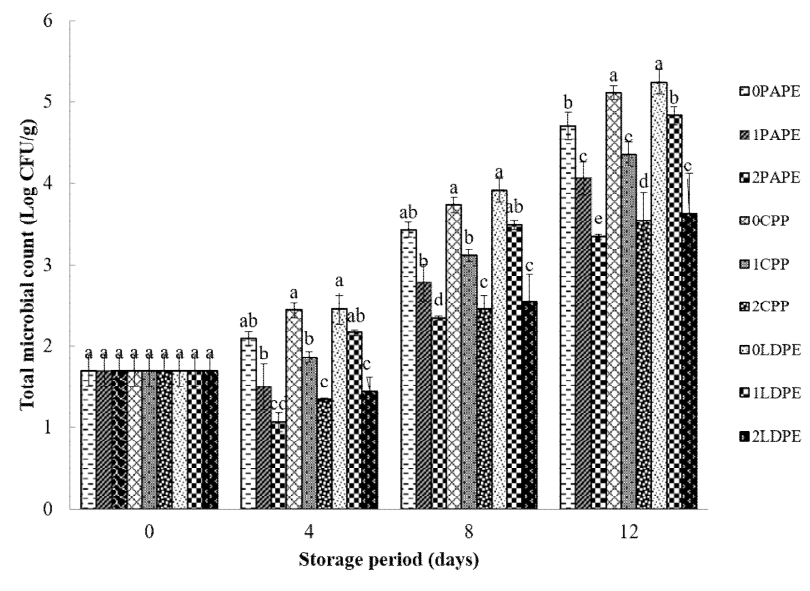

Fig. 7. Effect of chitosan coating and packaging material on total bacteria count of fresh-cut cucumber during storage.

0,1 , and 2 represent \% chitosan concentration, PAPE (polyamide-polyethylene), CPP (casted propylene film+polypropylene tray), and LDPE (low-density polyethylene) packaging materials.

\section{References}

1. Adamicki F, Elkner K (1985) Effect of storage and wrapping on the keeping quality of cucumber fruits. Acta Hortic, 156, 269-272

2. Coppens d'Eeckenbrugge G, Leal F, Bartholomew D, Paull R, Rohrbach K (2003) The pineapple: botany, production and uses. CABI Pub, Oxon, UK, p 13-32

3. Rocculi P, Cocci E, Romani S, Sacchetti G, Dalla Rosa $\mathrm{M}$ (2009) Effect of 1-MCP treatment and $\mathrm{N}_{2} \mathrm{O}$ MAP on physiological and quality changes of fresh-cut pineapple. Postharvest Biol Technol, 51, 371-377

4. Soliva-Fortuny RC, Martin-Belloso O (2003) New advances in extending the shelf-life of fresh-cut fruits: a review. Trends Food Sci Technol, 14, 341-353

5. Rojas-Grau MA, Tapia MS, Rodriguez FJ, Carmona AJ, Martin-Belloso O (2007) Alginate and gellan-based edible coatings as carriers of antibrowning agents applied on fresh-cut Fuji apples. Food Hydrocolloids, 21, 118-127

6. Silveira AC, Aguayo E, Chisari M, Artes F (2011) Calcium salts and heat treatment for quality retention of fresh-cut 'Galia'melon. Postharvest Biol Technol, 62, 77-84

7. Siddiq M, Roidoung S, Sogi DS, Dolan KD (2013) Total phenolics, antioxidant properties and quality of fresh-cut onions (Allium cepa L.) treated with mild-heat. Food Chem, 136, 803-806

8. Abreu M, Beirao-da-Costa S, Goncalves EM, Beirao-da-Costa ML, Moldao-Martins M (2003) Use of mild heat pre-treatments for quality retention of fresh-cut 'Rocha'pear. Postharvest Biol Technol, 30, 153-160

9. Sgroppo SC, Pereyra MV (2009) Using mild heat treatment to improve the bioactive related compounds on fresh-cut green bell peppers. Int J Food Sci Tech, 44, 1793-1801

10. Alegria C, Pinheiro J, Duthoit M, Goncalves EM, Moldao-Martins M, Abreu M (2012) Fresh-cut carrot (cv.nantes) quality as affected by abiotic stress (heat shock and UV-C irradiation) pre-treatments. LWT-Food Sci Technol, 48, 197-203

11. Oms-Oliu G, Soliva-Fortuny R, Marin-Belloso O (2008) Using polysaccharide-based edible coatings to enhance quality and antioxidant properties of fresh-cut melon. LWT-Food Sci Technol, 41, 1862-1870

12. Brasil IM, Gomes C, Puerta-Gomez A, Castell-Perez ME, Moreira RG (2012) Polysaccharide-based multilayered antimicrobial edible coating enhances quality of fresh-cut papaya. LWT-Food Sci. Technol, 47, 39-45

13. Benitez S, Soro L, Achaerandio I, Sepulcre F, Pujola M (2014) Combined effect of a low permeable film and edible coatings or calcium dips on the quality of fresh cut pineapple. J Food Process Eng, 37, 91-99

14. Poverenov E, Zaitsev $\mathrm{Y}$, Arnon H, Granit R, Alkalai-Tuvia S, Perzelan Y, Weinberg T, Fallik E (2014) Effects of a composite chitosan-gelatin edible coating on postharvest quality and storability of red bell peppers. Postharvest Biol Technol, 96, 106-109

15. Sanchis E, Gonzalez S, Ghidelli C, Sheth CC, Mateos M, Palou L, Perez-Gago MB (2016) Browning inhibition and microbial control in fresh-cut persimmon (Diospyros kaki Thunb. cv. Rojo Brillante) by apple pectin-based edible coatings. Postharvest Biol Technol, 112, 186-193

16. Yousuf B, Srivastava AK (2017) Flaxseed gum in combination with lemongrass essential oil as an effective edible coating for ready-to-eat pomegranate arils. Int $\mathbf{J}$ Biol Macromol, 104, 1030-1038

17. Gonzalez-Aguilar GA, Valenzuela-Soto E, Lizardi-Mendoza J, Goycoolea F, Martinez-Tellez MA, Villegas-Ochoa MA, Monroy-Garcia IN Ayala-Zavala, JF (2009) Effect of chitosan coating in preventing deterioration and preserving the quality of fresh cut papaya 'Maradol'. J Sci Food Agric ISO, 89, 15-23

18. Olivas GI, Barbosa-Canovas GV (2005) Edible coatings for fresh-cut fruits. Crit Rev Food Sci Nutr, 45, 657-670

19. Chien PJ, Chou CC (2006) Antifungal activity of chitosan and its application to control post-harvest quality and 
fungal rotting of Tankan citrus fruit (Citrus tankan Hayata). J Sci Food Agric, 86, 1964-1969

20. Chien PJ, Sheu F, Yang FH. (2007) Effects of edible chitosan coating on quality and shelf life of sliced mango fruit. J Food Eng, 78, 225-229

21. Sangsuwan J, Rattanapanone N, Rachtanapun P (2008) Effect of chitosan/methyl cellulose films on microbial and quality characteristics of fresh-cut cantaloupe and pineapple. Postharvest Biol Technol, 49, 403-410

22. Kong M, Chen XG, Xing K, Park HJ (2010) Antimicrobial properties of chitosan and mode of action: a state of the art review. Int J Food Microbiol, 144, 51-63

23. Meir S, Kanner J, Akiri B, Philosoph-Hadas S (1995) Determination and involvement of aqueous reducing compounds in oxidative defense systems of various senescing leaves. J Agric Food Chem, 43, 1813-1819

24. Arvanitoyannis IS, Oikonomou G (2012) Active and intelligent packaging. In modified Atmosphere and Active Packaging Technologies. CRC Press, USA, p 627-662.

25. Pereira de Abreu DA, Cruz JM, Paseiro Losada P (2012) Active and intelligent packaging for the food industry. Food Rev Int, 28, 146-187

26. Sandhu SS, Singh AP (2000) Effect of harvesting dates and individual seal packaging on the pear fruit cv. Le Conte during cold storage. Haryana J Hort Sci, 29, 48-52

27. Zhou, R., Mo, Y., Li, Y., Zhao, Y., Zhang, G., \& Hu, Y. (2008). Quality and internal characteristics of Huanghua pears (Pyrus pyrifolia Nakai, cv. Huanghua) treated with different kinds of coatings during storage. Postharvest Biol and Technol, 49, 171-179

28. Nath A, Deka BC, Singh A, Patel RK, Paul D, Misra LK, Ojha H (2012) Extension of shelf life of pear fruits using different packaging materials. J Food Sci Technol, 49, 556-563

29. Ros-Chumillas M, Belissario Y, Iguaz A, Lopez A (2007) Quality and shelf life of orange juice aseptically packaged in PET bottles. J Food Eng, 79, 234-242

30. Azene M, Workneh TS, Woldetsadik K (2014) Effect of packaging materials and storage environment on postharvest quality of papaya fruit. J Food Sci Technol, 51, 1041-1055

31. Ali A, Noh NM, Mustafa MA (2015) Antimicrobial activity of chitosan enriched with lemongrass oil against anthracnose of bell pepper. Food packaging and shelf life, 3, 56-61

32. Jia CG, Xu CJ, Wei J, Yuan J, Yuan GF, Wang BL,
Wang QM (2009) Effect of modified atmosphere packaging on visual quality and glucosinolates of broccoli florets. Food Chem, 114, 28-37

33. Luna-Guzman I, Cantwell M, Barrett DM (1999). Fresh-cut cantaloupe: effects of $\mathrm{CaCl}_{2}$ dips and heat treatments on firmness and metabolic activity. Postharvest Biol Technol, 17, 201-213.

34. Waghmare RB, Annapure US, (2013) Combined effect of chemical treatment and/or modified atmosphere packaging (MAP) on quality of fresh-cut papaya. Postharvest Biol Technol, 85, 147-153

35. Watkins CB (2000) Responses of horticultural commodities to high carbon dioxide as related to modified atmosphere packaging. HortTechnology, 10, 501-506

36. Watada AE, Ko NP, Minott DA (1996) Factors affecting quality of fresh-cut horticultural products. Postharvest Biol and Technol, 9, 115-125

37. Azarakhsh N, Osman A, Ghazali HM, Tan CP, Adzahan NM (2014) Lemongrass essential oil incorporated into alginate-based edible coating for shelf-life extension and quality retention of fresh-cut pineapple. Postharvest Biol Technol, 88, 1-7

38. Hernandez-Munoz P, Almenar E, Ocio MJ, Gavara R (2006) Effect of calcium dips and chitosan coatings on postharvest life of strawberries (Fragaria $x$ ananassa). Postharvest Biol Technol, 39, 247-253

39. Tanada-Palmu PS, Grosso CRF (2005) Effect of edible wheat gluten-based films and coatings on refrigerated strawberry (Fragaria ananassa) quality. Postharvest Biol Technol, 36, 199-208

40. Ali ZM, Chin LH, Lazan H (2004) A comparative study on wall degrading enzymes, pectin modifications and softening during ripening of selected tropical fruits. Plant Sci, 167, 317-327

43. Antunes M D C, Correia MP, Miguel M G, Martins M A, Neves M A (2003) The effect of calcium chloride postharvest application on fruit storage ability and quality of 'Beliana' and 'Lindo' apricot (Prunus armeniaca L.) cultivars. Acta Hortic, 604, 721-726

41. Campaniello D, Bevilacqua A, Sinigaglia M, Corbo MR (2008) Chitosan: Antimicrobial activity and potential applications for preserving minimally processed strawberries. Food Microbiol, 25, 992-1000

42. Carvalho RL, Cabral MF, Germano TA, De Carvalho WM, Brasil IM, Gallao MI, Moura CFH, Lopes MMA, De Miranda MRA (2016) Chitosan coating with trans-cinnamaldehyde improves structural integrity and 
antioxidant metabolism of fresh-cut melon. Postharvest Biol Technol, 113, 29-39

44. Jiang Y, Li Y (2001) Effects of chitosan coating on postharvest life and quality of longan fruit. Food Chem, 73, 139-143

45. Shao XF, Tu K, Tu S, Tu J (2012) A combination of heat treatment and chitosan coating delays ripening and reduced decay in "Gala" apple fruit. J Food Qual, 35, 83-92

46. Meng X, Zhang M, Zhan Z, Adhikari B (2014) Changes in quality characteristics of fresh-cut cucumbers as affected by pressurized argon treatment. Food Bioprocess Technol, 7, 693-701

47. Adekunte AO, Tiwari BK, CUllen PJ, Scannell AGM, O'Donnell CP (2010) Effect of sonication on colour, ascorbic acid and yeast inactivation in tomato juice. Food Chem, 122, 500-507

48. Jiang Y, Li J, Jiang W (2005) Effects of chitosan coating on shelf life of cold-stored litchi fruit at ambient temperature. LWT-Food Sci Technol, 38, 757-761

49. Varasteh F, Arzani K, Barzegar M, Zamani Z (2012) Changes in anthocyanins in arils of chitosan-coated pomegranate (Punica granatum L. cv. Rabbab-e-Neyriz) fruit during cold storage. Food Chem, 130, 267-272
50. Garcia-Garcia I, Taboada-Rodriguez A, Lopez-Gomez A, Marin-Iniesta F (2013) Active packaging of cardboard to extend the shelf life of tomatoes. Food Bioprocess Technol, 6, 754-761

51. Dong F, Li S, Jin C, Liu Z, Zhu K, Zou H, Wang X (2016) Effect of nanocellulose/chitosan composite coatings on cucumber quality and shelf life. Toxicol Environ Chem, 98, 450-461

52. Lynch MF, Tauxe RV, Hedberg CW (2009) The growing burden of foodborne outbreaks due to contaminated fresh produce: risks and opportunities. Epidemiol Infect, 137, 307-315

53. Li B, Wang X, Chen R, Huangfu W, Xie G (2008) Antibacterial activity of chitosan solution against Xanthomonas pathogenic bacteria isolated from Euphorbia pulcherrima. Carbohydr Polym, 72, 287-292

54. Park SI, Stan SD, Daeschel MA, Zhao Y (2005) Antifungal coatings on fresh strawberries (Fragaria $x$ ananassa) to control mold growth during cold storage. J Food Sci, 70, 202-207 